\section{Photobiomodulation Therapy (PBMT) Can be One of the Major Therapy in the Healthcare}

\author{
Jih-Huah $\mathbf{W u} \mathbf{u}^{*}$ \\ Department of Biomedical Engineering, Ming Chuan University, Taiwan
}

Photobiomodulation Therapy (PBMT) is regarded as an alternative or complementary medicine in the current therapy, however, this medical treatment will be one of the most recent trends in healthcare. In the modern world, the life span of human beings has been prolonged by the progress of science and technology. Nevertheless, at the beginning, elderly will have some mild illness or symptoms such as sleep and pain disorders due to the Qi or energy gradually reducing at this range of generation.

As we know, medicine may cause side effects which can lead to several serious symptoms then result in severe new diseases. This vicious circle can worsen human healthcare. In this article, I present the potential of PBMT which can treat the diseases of pain and sleep disorders and can help alleviate these symptoms, therefore the usage of conventional medicine can be reduced.

For pain disorder, analgesics are usually used to reduce pain, however they have many side effects which are serious and lethal. Nowadays, the symptoms of Post Herpes Neuralgia (PHN) can be improved by radiating the area with an $830 \mathrm{~nm}$ laser [1] which can moderate pain disorder instead of using Lyrica accompanied with unnecessary side effects. In our previous report, low back pain can be reduced by laser acupuncture [2,3] and in our animal study of PBMT [4], the pain factors can be reduced by radiating Zusanli (ST36) acupoint with laser acupuncture. PBMT can relieve pain and improve the healing process of Closed Bone Fractures (CBFs) in the human wrist and hand by $830 \mathrm{~nm}$ diode lasers [5]. In addition, PBMT was effective in alleviating pain and symptoms, and improving

*Corresponding author: Jih-Huah Wu, Department of Biomedical Engineering Ming Chuan University, Taoyuan, Taiwan, Tel: +886 0335070013951; E-mail wujh@mail.mcu.edu.tw

Citation: Wu J-H (2020) Photobiomodulation Therapy (PBMT) Can be One of the Major Therapy in the Healthcare. J Altern Complement Integr Med 6: 120

Received: September 23, 2020; Accepted: September 28, 2020; Published: October 07, 2020

Copyright: $\odot 2020 \mathrm{Wu} \mathrm{J-H}$. This is an open-access article distributed under the terms of the Creative Commons Attribution License, which permits unrestricted use, distribution, and reproduction in any medium, provided the original author and source are credited. functional ability and finger and hand strength for mild and moderate Carpal Tunnel Syndrome (CTS) patients with no side effects [6,7]. A systematic review and meta-analysis results revealed that applying PBMT on tender points or Myofascial Trigger Points (MTrPs) is an effective means to improve the Effect Size (ES) of pain release after treatment and follow-up [8]. Many researches and our studies reveal that PBMT can help pain relief, so the use of analgesics can be reduced. Further, the side effects caused by medicine can be reduced too.

In clinical, sleep disorders can almost be improved by using medication. For instance, insomnia is one of the most commonly reported sleep problems. Although taking medicine for treating short term insomnia is not a serious issue, long term insomnia can cause serious side effects, including deficiency of attention, lower immunity, even accidents. In 2009, we used a single laser to radiate the Neiguan acupoint on night shift workers to adjust their Parasympathetic Nervous System (PSN) and Heart Rate Variability (HRV) [9]. In 2012, we used an array laser to radiate the left palm of the subjects. Their brain waves were changed, especially $\alpha$ band had been increased in some regions and $\beta$ band had been decreased for normal subjects in open eyes condition [10]. In closed eyes study, the alpha diffusion in the frontal lobe has been found in the laser group, it means the PBMT can help induce sleep [11]. Excepting medication, other alternative or complementary therapies are used to treat sleep problems, like as Massage Therapy, Energy Medicine, Aromatherapy, Tai Chi, Qi Gong etc. However, PBMT is the advanced way which can be operated and combined with other therapies to improve the efficiency of treatment. Moreover, PBMT can also adjust the rhythm in our body. Chronobiology is a science that study the time rhythm in our body; it means the endogenous substances in our body are controlled by circadian rhythm. Normally, the Qi in our body follow the exactly time to go through our organs according to the sequences: Gall bladder meridian (11 PM to 1:00 AM) $\square$ Liver meridian (1:00 $\mathrm{AM}$ to 3:00 AM) Lung meridian (3:00 AM to 5:00 AM), etc., as shown in figure 1. Stay-up late and jet lag will change the circadian rhythm. We just need to stimulate the specific acupoint of meridian in specific periods. The circadian rhythm can be adjusted quickly, it means that the use of serotonin will be reduced too. For example, to stimulate Shangyang acupoint (Large intestine meridian) during 5 AM to 7 AM, Zhongchong acupoint (Pericardium meridian) during 7 PM to 9 PM and Guanchong acupoint (Triple energizer meridian) during 9 PM to 11 PM can help adjust the circadian rhythm, as shown in figure 2(a). Real operation of laser acupuncture is shown in figure 2(b).

From many scientific reports and our studies, PBMT has high potential to replace parts of conventional therapies. Due to the light energy input, it can energize the cells in our body and make the meridians connect organs smoothly. It can help to prevent diseases caused by aging. The side effects of medication will be reduced tremendously because of the reduction of drug use. Human health will be improved apparently. 

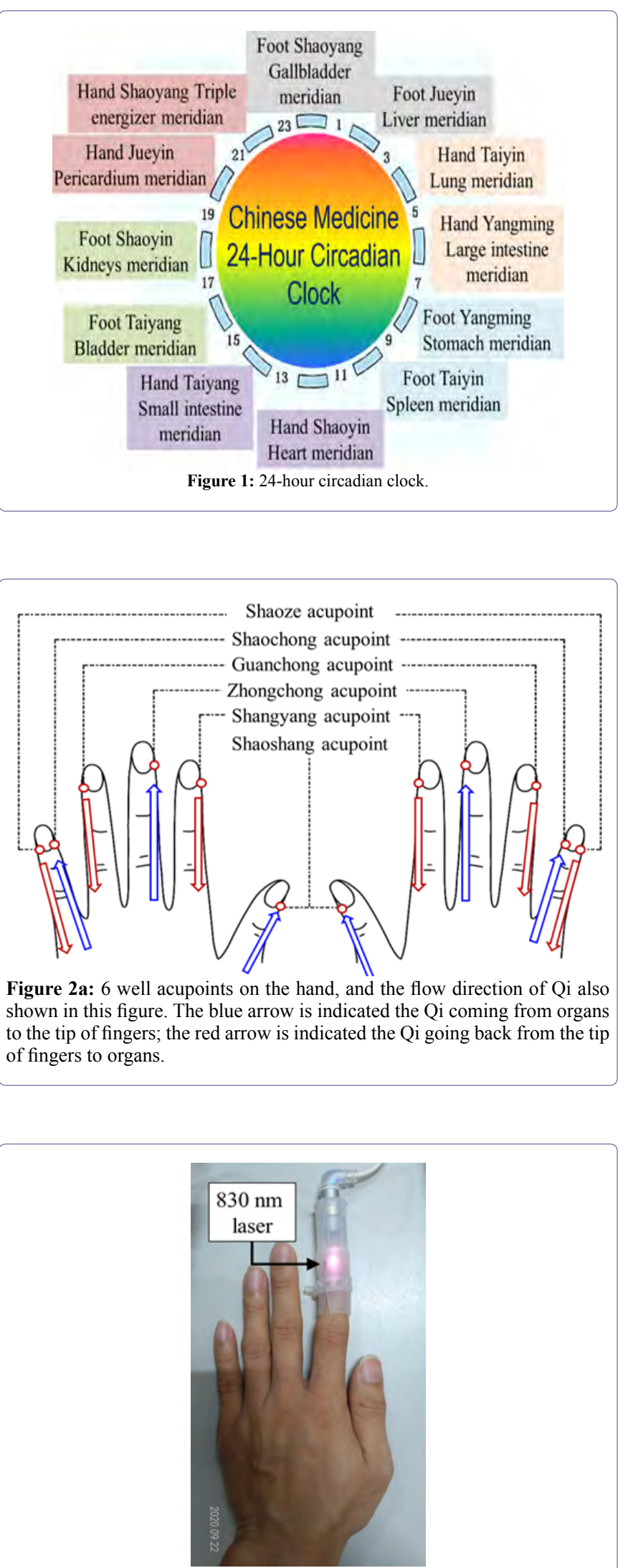

Figure 2b: Real operation of laser acupuncture on well acupoint.

\section{References}

1. Kemmotsu O, Sato K, Furumido H, Harada K, Takigawa C, et al. (1991) Efficacy of low reactive-level laser therapy for pain attenuation of postherpetic neuralgia. Laser Therapy 3: 71-75.

2. Lin M-L, Wu H-C, Hsieh Y-H, Su C-T, Shih Y-S, et al. (2012) Evaluation of the effect of laser acupuncture and cupping with ryodoraku and visual analog scale on low back pain. Evid Based Complement Alternat Med 2012: 521612 .

3. Lin M-L, Wu J-H, Lin C-W, Su C-T, Wu H-C, et al. (2017) Clinical effects of laser acupuncture plus Chinese cupping on the pain and plasma cortisol levels in patients with chronic nonspecific lower back pain: a randomized controlled trial. Evid Based Complement Alternat Med 2017: 3140403.

4. Zeng Y-J, Lin Y-H, Wang Y-C, Chang J-H, Wu J-H,et al. (2018) Laser acupuncture-induced analgesic effect and molecular alterations in an incision pain model: a comparison with electroacupuncture-induced effects. Laser Med Sci 33: 295-304.

5. Chang W-D, Wu J-H, Wang H-J, Jiang J-A (2014) Therapeutic outcomes of low-level laser therapy for closed bone fracture in the human wrist and hand. Photomed Laser Surg 32: 212-218.

6. Chang W-D, Wu J-H, Jiang J-A, Yeh C-Y, Tsai C-T (2008) Carpal tunnel syndrome treated with a diode laser: a controlled treatment of the transverse carpal ligament. Photomed Laser Surg 26: 551-557.

7. Jiang J-A, Chang W-D, Wu J-H, Lai P-T, Lin H-Y (2011) Low-level laser treatment relieves pain and neurological symptoms in patients with carpal tunnel syndrome. Phys Ther Sci 23: 661-665.

8. Chang W-D, Wu J-H, Yang W-J, Jiang J-A (2010) Therapeutic effects of low-level laser on lateral epicondylitis from differential interventions of Chinese-Western medicine: systematic review. Photomed Laser Surg 28: 327-336.

9. Wu J-H, Chen H-Y, Chang Y-J, Wu H-C, Chang W-D, et al. (2009) Study of autonomic nervous activity of night shift workers treated with laser acupuncture. Photomed Laser Surg 27: 273-279.

10. Wu J-H, Chang W-D, Hsieh C-W, Jiang J-A, Fang W, et al. (2012) Effect of low level laser stimulation on EEG. Evid Based Complement Alternat Med 2012: 951272.

11. Wu J-H, Chang Y-C (2013) Effect of Low-Level Laser Stimulation on EEG Power in Normal Subjects with Closed Eyes. Evid Based Complement Alternat Med 2013: 476565. 


\section{di \\ нramb}

Advances In Industrial Biotechnology | ISSN: 2639-5665

Advances In Microbiology Research | ISSN: 2689-694X

Archives Of Surgery And Surgical Education | ISSN: 2689-3126

Archives Of Urology

Archives Of Zoological Studies | ISSN: 2640-7779

Current Trends Medical And Biological Engineering

International Journal Of Case Reports And Therapeutic Studies | ISSN: 2689-310X

Journal Of Addiction \& Addictive Disorders | ISSN: 2578-7276

Journal Of Agronomy \& Agricultural Science | ISSN: 2689-8292

Journal Of AIDS Clinical Research \& STDs | ISSN: 2572-7370

Journal Of Alcoholism Drug Abuse \& Substance Dependence | ISSN: 2572-9594

Journal Of Allergy Disorders \& Therapy | ISSN: 2470-749X

Journal Of Alternative Complementary \& Integrative Medicine | ISSN: 2470-7562

Journal Of Alzheimers \& Neurodegenerative Diseases | ISSN: 2572-9608

Journal Of Anesthesia \& Clinical Care | ISSN: 2378-8879

Journal Of Angiology \& Vascular Surgery | ISSN: 2572-7397

Journal Of Animal Research \& Veterinary Science | ISSN: 2639-3751

Journal Of Aquaculture \& Fisheries | ISSN: 2576-5523

Journal Of Atmospheric \& Earth Sciences | ISSN: 2689-8780

Journal Of Biotech Research \& Biochemistry

Journal Of Brain \& Neuroscience Research

Journal Of Cancer Biology \& Treatment | ISSN: 2470-7546

Journal Of Cardiology Study \& Research | ISSN: 2640-768X

Journal Of Cell Biology \& Cell Metabolism | ISSN: 2381-1943

Journal Of Clinical Dermatology \& Therapy | ISSN: 2378-8771

Journal Of Clinical Immunology \& Immunotherapy | ISSN: 2378-8844

Journal Of Clinical Studies \& Medical Case Reports | ISSN: 2378-8801

Journal Of Community Medicine \& Public Health Care | ISSN: 2381-1978

Journal Of Cytology \& Tissue Biology | ISSN: 2378-9107

Journal Of Dairy Research \& Technology | ISSN: 2688-9315

Journal Of Dentistry Oral Health \& Cosmesis | ISSN: 2473-6783

Journal Of Diabetes \& Metabolic Disorders | ISSN: 2381-201X

Journal Of Emergency Medicine Trauma \& Surgical Care | ISSN: 2378-8798

Journal Of Environmental Science Current Research | ISSN: 2643-5020

Journal Of Food Science \& Nutrition | ISSN: 2470-1076

Journal Of Forensic Legal \& Investigative Sciences | ISSN: 2473-733X

Journal Of Gastroenterology \& Hepatology Research | ISSN: 2574-2566
Journal Of Genetics \& Genomic Sciences | ISSN: 2574-2485

Journal Of Gerontology \& Geriatric Medicine | ISSN: 2381-8662

Journal Of Hematology Blood Transfusion \& Disorders | ISSN: 2572-2999

Journal Of Hospice \& Palliative Medical Care

Journal Of Human Endocrinology | ISSN: 2572-9640

Journal Of Infectious \& Non Infectious Diseases | ISSN: 2381-8654

Journal Of Internal Medicine \& Primary Healthcare | ISSN: 2574-2493

Journal Of Light \& Laser Current Trends

Journal Of Medicine Study \& Research | ISSN: 2639-5657

Journal Of Modern Chemical Sciences

Journal Of Nanotechnology Nanomedicine \& Nanobiotechnology | ISSN: 2381-2044 Journal Of Neonatology \& Clinical Pediatrics | ISSN: 2378-878X

Journal Of Nephrology \& Renal Therapy | ISSN: 2473-7313

Journal Of Non Invasive Vascular Investigation | ISSN: 2572-7400

Journal Of Nuclear Medicine Radiology \& Radiation Therapy | ISSN: 2572-7419

Journal Of Obesity \& Weight Loss | ISSN: 2473-7372

Journal Of Ophthalmology \& Clinical Research | ISSN: 2378-8887

Journal Of Orthopedic Research \& Physiotherapy | ISSN: 2381-2052

Journal Of Otolaryngology Head \& Neck Surgery | ISSN: 2573-010X

Journal Of Pathology Clinical \& Medical Research

Journal Of Pharmacology Pharmaceutics \& Pharmacovigilance | ISSN: 2639-5649

Journal Of Physical Medicine Rehabilitation \& Disabilities | ISSN: 2381-8670

Journal Of Plant Science Current Research | ISSN: 2639-3743

Journal Of Practical \& Professional Nursing | ISSN: 2639-5681

Journal Of Protein Research \& Bioinformatics

Journal Of Psychiatry Depression \& Anxiety | ISSN: 2573-0150

Journal Of Pulmonary Medicine \& Respiratory Research | ISSN: 2573-0177

Journal Of Reproductive Medicine Gynaecology \& Obstetrics | ISSN: 2574-2574

Journal Of Stem Cells Research Development \& Therapy | ISSN: 2381-2060

Journal Of Surgery Current Trends \& Innovations | ISSN: 2578-7284

Journal Of Toxicology Current Research | ISSN: 2639-3735

Journal Of Translational Science And Research

Journal Of Vaccines Research \& Vaccination | ISSN: 2573-0193

Journal Of Virology \& Antivirals

Sports Medicine And Injury Care Journal | ISSN: 2689-8829

Trends In Anatomy \& Physiology | ISSN: 2640-7752

Submit Your Manuscript: https://www.heraldopenaccess.us/submit-manuscript 